by Raj K. Singh* and Anil K. Gupta**

\title{
Deep-sea benthic foraminiferal changes in the eastern Indian Ocean (ODP Hole 757B): Their links to deep Indonesian (Pacific) flow and high latitude glaciation during the Neogene
}

\author{
Department of Geology and Geophysics, Indian Institute of Technology, Kharagpur, 721302, India. \\ E-mail: rajkursingh@yahoo.com,anilg@gg.iitkgp.ernet.in \\ *Present address: Central Ground Water Board, Mid-Eastern Region, Patna, India \\ ** Communicating author
}

This study analyses $26.5 \mathrm{Ma}$ record of deep-sea benthic foraminifera from 194 samples from Ocean

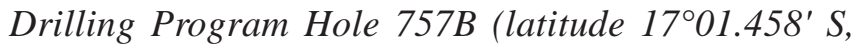
longitude $88^{\circ} 10.899^{\prime} \mathrm{E}$, water depth of $1652.1 \mathrm{~m}$ ) located on the Ninetyeast Ridge, southeastern Indian Ocean below equatorial divergence zone. The data document important changes in benthic foraminiferal population at Hole $757 B$ since the late Oligocene. The welloxygenated, oligotrophic species including Cibicides cicatricosus, C. pseudoungerianus and Oridorsalis umbonatus were dominant during the late Oligocene to the early Miocene. These species began to decline as site 757 moved northward into the influence of the Indonesian Throughflow (ITF) beneath surface and subsurface water masses from the Pacific Ocean. Cibicides cicatricosus and $\mathrm{C}$. pseudoungerianus disappeared in the late Miocene (10-8 Ma) at Hole 757B. The lower bathyal to abyssal species Nuttallides umbonifera shows a major increase at $\sim 11.5 \mathrm{Ma}$ coinciding with a significant increase in Neodymium (Nd) isotope values, indicating substantial transport of deep Pacific water to the Indian Ocean through the Indonesian seaway. Nuttallides umbonifera decreases drastically during 3-2.8 Ma, though the Nd isotope values do not show a decrease. We relate this change to a low sample resolution in the latter study. This event coincides with the final closure of the Indonesian seaway and a switch in shallow ITF source from warm, saline South Pacific to cool, fresh North Pacific thermocline water, which triggered global cooling and major expansion of Northern Hemisphere glaciation.

\section{Introduction}

The opening and closing of the seaways and high latitude glaciation drive important changes in thermocline and thermohaline circulation of ocean basins, impacting surface and deep-sea biota as well as regional and global climates. For example, closure of the Indonesian seaway during the early Pliocene (4-3 Ma) triggered important climatic changes including cooling of the global thermocline, major expansion of Northern Hemisphere ice sheets, and African aridification (Cane and Molnar, 2001; Karas et al., 2009). Likewise, a major increase in the Antarctic glaciation during the middle Miocene impacted deep-sea biota (e.g., Gupta et al., 2004). The Indonesian seas provide a passage for substantial transport of Pacific Ocean waters into the Indian Ocean called as the Indonesian Throughflow (ITF) (Gordon, 1986; Wyrtki, 1987). The ITF transfers water from the Pacific Ocean to the Indian Ocean in the thermocline layer, which influences heat and freshwater budgets of the two oceans (Gordon and Fine 1996; Godfrey, 1996).

The constriction of the Indonesian seaway due to northward movement of New Guinea in the early Pliocene changed the source of ITF, leading to aridification of east Africa and major expansion of the Northern Hemisphere glaciation (NHG) (Cane and Molnar, 2001). The constriction of the seaway obstructed the deeper connection between the two ocean basins, leading to significant reduction of transport of intermediate to deep Pacific waters to the Indian Ocean. While seasonal as well as geological variability in ITF (thermocline water) has been analyzed in greater detail in numerous recent studies (e.g. Gordon and Fine, 1996; Cane and Molnar, 2001, Gordon et al., 2003; Karas et al., 2009) little is known about the lower bathyal (intermediate) to abyssal (deep) flow from the Pacific to the Indian Ocean during the Neogene. The only study from this region by Martin and Scher (2006) suggests an extensive transport of intermediate water through the Indonesian seaway from 10 to $5.5 \mathrm{Ma}$ and stepwise reduction from 5.5 to 3.4 Ma using Neodymium (Nd) isotope data of fish teeth from Hole 757B. Though this study provides useful information on the intermediate to deep water flow from the Pacific to the Indian Ocean, the study is at very low sample resolution which may have failed to capture exact timing of the events related to ITF 
variability. The present study is aimed at understanding deep-sea paleoceanographic changes in the eastern Indian Ocean and their link with Pacific deep water flow as well as high latitude glaciation by analyzing conventional proxies - deep-sea benthic foraminifera, from Ocean Drilling Program (ODP) Hole 757B at higher resolution (Annexure I) combined with $\mathrm{Nd}$ isotope data of Martin and Scher (2006).

\section{Site Location and Oceanographic Settings of Hole 757B}

Hole 757B is located on the Ninetyeast Ridge, eastern Indian Ocean, at a latitude of $17^{\circ} 01.458^{\prime} \mathrm{S}$, longitude of $88^{\circ} 10.899^{\prime} \mathrm{E}$, and water depth of $1652.1 \mathrm{~m}$ in the southeastern Indian Ocean below equatorial divergence zone on the northern edge of the subtropical gyre and somewhat south of the South Equatorial Current or main ITF path (Fig. 1).

Hole 757B is currently bathed by Indian Deep Water (IDW) - a water mass with a potential temperature of $1.25-4^{\circ} \mathrm{C}$, a salinity maximum of $\sim 34.7-34.8$ and oxygen of $\sim 4.7 \mathrm{ml} / \mathrm{L}$ (Tomczak and Godfrey, 2003). This water mass occupies 500 to $3800 \mathrm{~m}$ water depths with a core at $\sim 2400 \mathrm{~m}$ (Tomczak and Godfrey, 2003). GEOSECS data (1983) indicate that the water above Hole 757B has a temperature of $3.1^{\circ} \mathrm{C}, \mathrm{PO}_{4}$ content of $0.055 \mathrm{ml} / \mathrm{L}, \mathrm{NO}_{3}$ content of $0.78 \mathrm{ml} / \mathrm{L}$, dissolve oxygen (DO) concentration of $\sim 3.20 \mathrm{ml} / \mathrm{L}$. At present, the

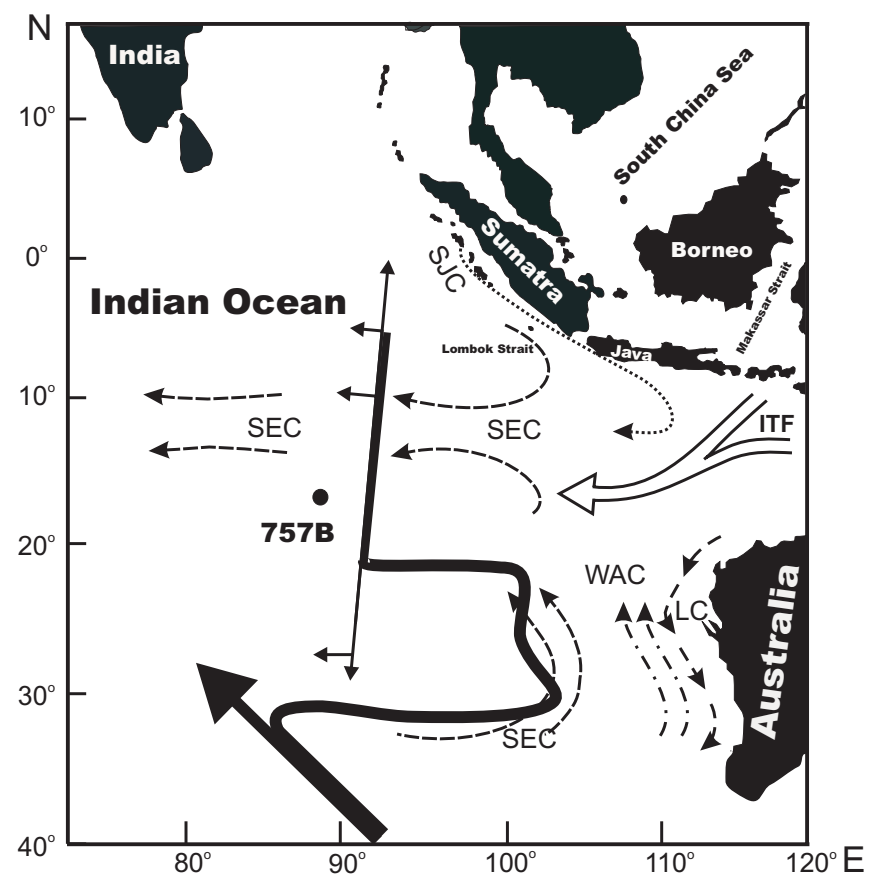

Figure 1. Location of Ocean Drilling Program Hole $757 \mathrm{~B}$ with surface and deep water currents. The black solid arrow marks the routes of Antarctic Bottom Water in the eastern Indian Ocean (Warren and Johnson, 2002). The hollow, large arrow shows the path of deep Pacific waters through the Indonesian seaway during late Miocene to Pliocene. The broken arrows are surface currents. ITF = Indonesian Throughflow, $L C=$ Leeuwin Current, $S J W=$ South Java Current, SEC = South Equatorial Current, WAC = West Australian Current.
IDW originates as North Atlantic Deep Water (NADW) which is pushed into the Indian Ocean with the Antarctic Circumpolar Water (CPW) (Tomczak and Godfrey, 2003). The water mass below $4000 \mathrm{~m}$ is mainly Antarctic Bottom Water (AABW) that flows in the area of Hole 757B through gaps in the Broken Ridge (Warren and Johnson, 2002) (Fig. 1). The IDW mixes with AABW below $2500 \mathrm{~m}$ and looses its identity. The surface water mass above Hole 757B is modulated by the low salinity waters of ITF and Sumatra-Java Current (Fig. 1). The heat and water exchange between the Indian and Pacific Oceans takes place through the ITF, which increases the surface temperature in the eastern Indian Ocean (Gordon et al., 2003).

Hole $757 \mathrm{~B}$ was located at $45^{\circ} \mathrm{S}$ at a water depth of $1500 \mathrm{~m}$ in the early Eocene ( $\sim 50 \mathrm{Ma})$, and at $29^{\circ} \mathrm{S}$ in a temperate region near the subtropical convergence zone at a water depth of $1500 \mathrm{~m}$ across the Oligocene-Miocene boundary ( 23.5 Ma) (Peirce et al., 1989). This site shifted to $21^{\circ} \mathrm{S}$ at $\sim 10 \mathrm{Ma}$ and to $18^{\circ} 30^{\prime} \mathrm{S}$ at $\sim 5 \mathrm{Ma}$ (Peirce et al., 1989). Thus paleolatitude study suggests that Site 757 was close to the present day location by $\sim 10 \mathrm{Ma}$ (Peirce et al., 1989) under the influence of the Indian monsoon that began to intensify around that time (Kroon et al., 1991). The deep water mass in the vicinity of Hole 757B may have been of Pacific origin during the Miocene to the early Pliocene because the deep Indonesian passage was open during that time.

\section{Indonesian Seaway and the Indonesian Throughflow}

Transport of water from the Pacific Ocean to the Indian Ocean through the Indonesian seaway is accomplished mainly in the thermocline layer which is drawn from the North Pacific (Gordon and Fine, 1996). Whereas the surface and thermocline components of the ITF move towards the Indian Ocean without significant impedance by topography, below thermocline depths numerous sills separating the basins of the Indonesian seas impede throughflow. The lower thermocline and deeper water is more saline and of South Pacific origin (Gordon and Fine, 1996). The deepest link between the Indian Ocean and Indonesian seas and bulk of transport of Indonesian Sea water occurs in the vicinity of Timor involving an array of passages along the Timor Passage and across the Outer Banda Arc (Gordon et al., 2003). Fieux et al. (1996) suggested a sill depth near Timor at 1200-1300 m, whereas Van Anken et al. (1988) found a sill near $1450 \mathrm{~m}$. The cooler, more saline and better oxygenated deep water in Timor Passage below $1500 \mathrm{~m}$ is derived from the Indian Ocean (Fieux et al., 1996). Exchange between Banda and Timor Seas is blocked below $1450 \mathrm{~m}$.

The volume and composition of ITF waters have varied through time. An open connection between the Pacific and Indian Oceans existed through Tethys prior to the Miocene (Martine and Scher, 2006). The destruction of the Tethys led to the progressive restriction of the seaway from the early to the late Miocene. The deep pathways between the Pacific and Indian Oceans largely closed in the latest Miocene at $\sim 6 \mathrm{Ma}$ (Nishimura and Suparka, 1997), and the Indonesian seaway finally constricted in the early Pliocene 4-3 Ma that led to a switch in the source of thermocline water from the South Pacific to the North Pacific Ocean (Cane and Molnar, 2001). The closing of deep connections between the Pacific and Indian Oceans may have driven significant changes in the thermohaline circulation and deep- 
sea biota of the eastern Indian Ocean, as well as regional climatic shifts.

\section{Materials and Methods}

We analyzed 194 samples of $10 \mathrm{cc}$ volume spanning the past 26.5 Ma after processing with the standard methods as given in Gupta and Thomas (1999). Core samples were soaked in clean water with half spoon of baking soda for 8-12 hours. Wet samples were washed over a $63 \mu \mathrm{m}$ size sieve, dried in an electric oven at $\sim 50^{\circ} \mathrm{C}$ temperature and transferred into labeled glass vials. Processed dry samples were split into suitable aliquots to obtain $\sim 300$ specimens of benthic foraminifera from $>125 \mu \mathrm{m}$ size fraction. This size fraction allows a comparison with numerous studies on deep-sea benthic foraminifera and water masses carried out on sediments from different ocean basins. Specimens of benthic foraminifera were identified up to species level, counted and their percentages were calculated. Dominant species with at least $10 \%$ or more population in any given sample are plotted combined with published $\mathrm{Nd}$ isotope data of fish teeth from Hole 757B (Martin and Scher, 2006) in Figs. 2-3. Preservation of benthic foraminifera was good throughout the studied interval. Interpolated ages for each sample are based on nannofossil datums of Peirce et al. (1989) and updated to Berggren et al. (1995). The average time resolution per sample is $\sim 137 \mathrm{Kyr}$ based on interpolated ages.

\section{Deep-sea Benthic Foraminifera and their Environments}

Benthic foraminifera are an important constituent of deep-sea environments living at all depths up to carbonate compensation depth and at all latitudes from tropics to poles. Because of their good fossilization potential, benthic foraminifera are reliable proxy to understand nature of deep water masses in the geologic past. Numerous studies provide an insight into the factors controlling the distribution of benthic foraminifera (Herb, 1971; Streeter, 1973; Schnitker, 1974; Lohmann, 1978; Corliss, 1979; Thomas, 1992; Hermelin and Shimmield, 1995; Gupta, 1994; Smart and Murray, 1994; Gupta and Thomas, 1999, 2003). Some studies suggest that distribution patterns of benthic foraminifera are closely related to organic carbon flux or organic carbon content of sediments (Miller and Lohmann, 1982; Altenbach and Sarnthein, 1989; Gooday, 1988, 1993; Schmiedl et al., 1997; De Stigter et al., 1998). Other studies emphasize on sensitivity of benthic foraminifera to oxygen levels of the bottom water and pore water oxygenation (Corliss, 1985; Sen Gupta and Machain-Castillo, 1993; Gooday, 1994; Loubere, 1996; Jannink et al., 1998). Benthic foraminifera occupy perched epibenthic to deep infaunal microhabitats and utilize diverse trophic mechanisms (De Stigter et al., 1998; Corliss, 1985). Their good fossilization potential and often considerable population make them useful tool in paleoceanographic and paleoclimatic studies.

The environmental preference of Cibicides cicatricosus is not well constrained. This species has been found associated with various biofacies indicative of different environmental condition in the southeastern Indian Ocean (Singh and Gupta, 2004). The species has numerous large size pores on its spiral side which suggest preference of this species to more oxygenated condition.
Cibicides pseudoungerianus, a species closely resembling C. ungerianus, is known to be intolerant to low-oxygen conditions (Barmawidjaja et al., 1992; den Dulk, 2000) and is typical of upper bathyal depths (700 and $2000 \mathrm{~m}$ ) where water temperature is higher than $2.5-3^{\circ} \mathrm{C}$ and carbon flux $>2.5 \mathrm{~g} \mathrm{C} \mathrm{m}^{-2}$ year ${ }^{-1}$ (Altenbach et al., 1999; Murgese and De Deckker, 2005). According to Barbieri (1998), it is typical of neritic to bathyal depths while Spencer (1996) correlated it with bathyal settings. This species is inferred to indicate high oxygen and low organic carbon condition.

Cibicides wuellerstorfi has been considered as a raised epibenthic species that prefers to live in high energy environments (Lutze and Thiel, 1989; Mackensen et al., 1995). In the Arctic Basin and in the Norwegian-Greenland Sea, the high abundance of this species has been suggested to reflect scarcity of food particles in the sediment (Linke and Lutze, 1993). As a suspension feeder and elevated epibiont, C. wuellerstorfi can survive on low organic carbon levels and can withstand strong bottom currents (Linke and Lutze, 1993). Loubere and Fariduddin (1999) considered it an indicator of high seasonal food supply under oligotrophic conditions. In the Indian Ocean, $C$. wuellerstorfi and $N$. umbonifera have been found associated with AABW (Corliss, 1979, 1983; Bremer and Lohmann, 1982), whereas in the Atlantic and Southern Oceans, $C$. wuellerstorfi has been associated with young, well-oxygenated water masses like NADW (Mackensen et al., 1995; Schmiedl and Mackensen, 1997; Gooday, 2003). Thus, $C$. wuellerstorfi can endure low organic carbon levels and strong bottom currents as a suspension feeder and an elevated epibiont (Linke and Lutze, 1993). Gupta (1997) relates this species with the oxygenated, strong bottom currents and strongly pulsed food supply in the Indian Ocean.

Ehrenbergina carinata thrives in high temperature, low oxygen and high nutrient levels (Nomura, 1991; Gupta and Satpathy, 2000). Gupta et al. (2006) suggested that E. carinata is indicative of intermediate to high flux of organic matter and low oxygen condition in the central Indian Ocean. At Hole 757B, this relationship does not hold true.

Epistominella exigua is an epibenthic, cosmopolitan, abyssal species, which feeds opportunistically on phytodetritus deposited seasonally on the sea floor (Gooday, 1988; Gooday and Turley, 1990; Smart and Murray, 1994; Thomas et al., 1995). Loubere and Fariduddin (1999) suggested that this species is most abundant at highly seasonal food fluxes that occur more than once a year (e.g., spring and fall blooms). This species reflects intermediate to high flux, high seasonality and well-oxygenated condition in tropical and northeastern Indian Ocean (Gupta and Thomas, 2003; Gupta et al., 2008). Murgese and De Deckker (2005) suggested that this species prefers a cold and well-oxygenated environment, where carbon flux to the sea floor is low. This species is indicative of high oxygen, low organic carbon, and high seasonality condition.

Globocassidulina subglobosa is a cosmopolitan species occurring over a wide range of bathymetry and in association with a number of different water masses. Fariduddin and Loubere (1997) observed this species associated with the NADW in the Atlantic Ocean and categorized it as a low-productivity species. In the South Atlantic, high abundances of G. subglobosa occur within the depth range of Circumpolar Deep Water (CDW) and in oligotrophic areas at higher elevations of ridges and submarine hills (Schnitker, 1980; Mackensen et al., 1995). In the South China Sea, G. subglobosa was observed tolerating warm waters (Miao and Thunell, 1993). In the southeastern Indian Ocean, G. subglobosa has been found associated with the 


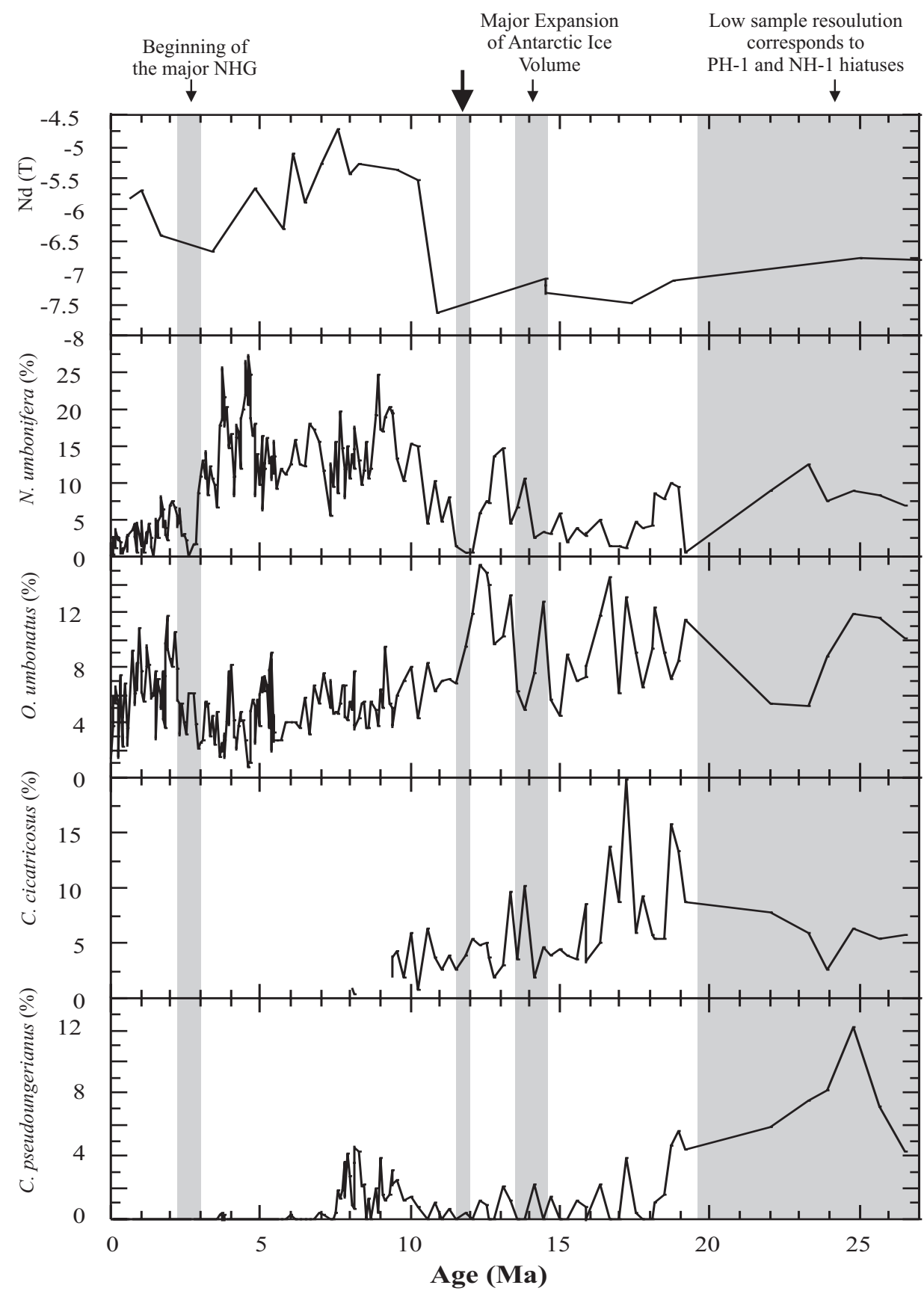

Figure 2. Percent distribution of Cibicides pseudoungerianus, Cibicides cicatricosus, Oridorsalis umbonatus and Nuttallides umbonifera at Hole 757 B combined with Neodymium (Nd) isotope values (Martin and Scher, 2006). Nuttallides umbonifera and Nd isotope values show a major increase at 11.5 Ma (thick arrow), during which time Oridorsalis umbonatus decreased indicating substantial transport of cold, corrosive deep Pacific flow to the Indian Ocean. Nuttallides umbonifera shows a major decrease whereas Oridorsalis umbonatus shows an increase during 3-2.8 Ma indicating a substantial reduction or complete shutdown of deep water from the Pacific. We do not see a major change in Nd isotope values during 3-2.8 Ma owing to low sample resolution or constriction of the Indonesian Throughflow.

AABW (Corliss, 1979). This species has also been suggested to feed on phytodetritus (Gooday, 1994) and a pulsed food supply to the seafloor in the northeastern Indian Ocean (Gupta and Thomas, 2003). Ohkushi et al. (2000) suggested that Globocassidulina lives in areas with enhanced, continuous food supply. This taxon is often found abundant in the sediments receiving lower organic matter in the regions where strong bottom currents are likely to occur (Schmiedl et al., 1997). Singh and Gupta (2004) suggested that this species reflects well-oxygenated deep waters having strongly pulsed food supply and good carbonate preservation in commonly oligotrophic environments in the southeastern Indian Ocean. At Hole 757B, this species is inferred to indicate high oxygen and low organic carbon water mass similar to CDW or NADW.

The environmental preferences of Nuttallides umbonifera have widely been debated. The species has been inferred to be an indicator of AABW (Streeter, 1973; Lohmann, 1978; Mackensen et al., 1995), but this relation is not visible in the southeastern Atlantic Angola Basin (Van Leeuwen, 1989). Bremer and Lohmann (1982) have linked abundant occurrences of this species to the presence of corrosive bottom water or AABW, whilst others have interpreted it as an indicator of low food supply (Gooday, 1994; Loubere and Fariduddin, 1999). Since the AABW is welloxygenated and occurs at greater depths in the modern oceans, the relatively lesser amount of organic carbon reaching these depths can be easily oxidized, and the $\mathrm{CO}_{2}$ produced by oxidation causes carbonate corrosiveness (Gupta, 1997). Considering all published studies, we suggest that $N$. umbonifera has a stronger relation with carbonate corrosivity than any other environmental factor.

Oridorsalis umbonatus is a long ranging species, which lives in a variety of environments (Gupta, 1990; Miao and Thunell, 1993; Schmiedl and Mackensen, 1997; Gupta and Thomas, 1999). It is an important cosmopolitan taxon of lower bathyal and abyssal faunas associated with $\mathrm{AABW}$ in the Indian Ocean (Corliss, 1979; Gupta, 1994), in the Atlantic (Streeter and Schackleton, 1979) and in the Antarctic (Uchio, 1960). In the Sulu Sea, this species reflects low organic carbon and higher carbonate saturation levels of the bottom waters, having a positive relation with carbonate saturation levels (Miao and Thunell, 1993). Mackensen et al. (1995) consider Oridorsalis to be living in well-oxygenated, low organic carbon deep-sea conditions, whereas Kaiho (1999) considered Oridorsalis to be an indicator of suboxic bottom waters. Rathburn and Corliss (1994) reported it in a transitional infaunal microhabitat, capable of surviving in a foodlimited and low oxygen condition. 


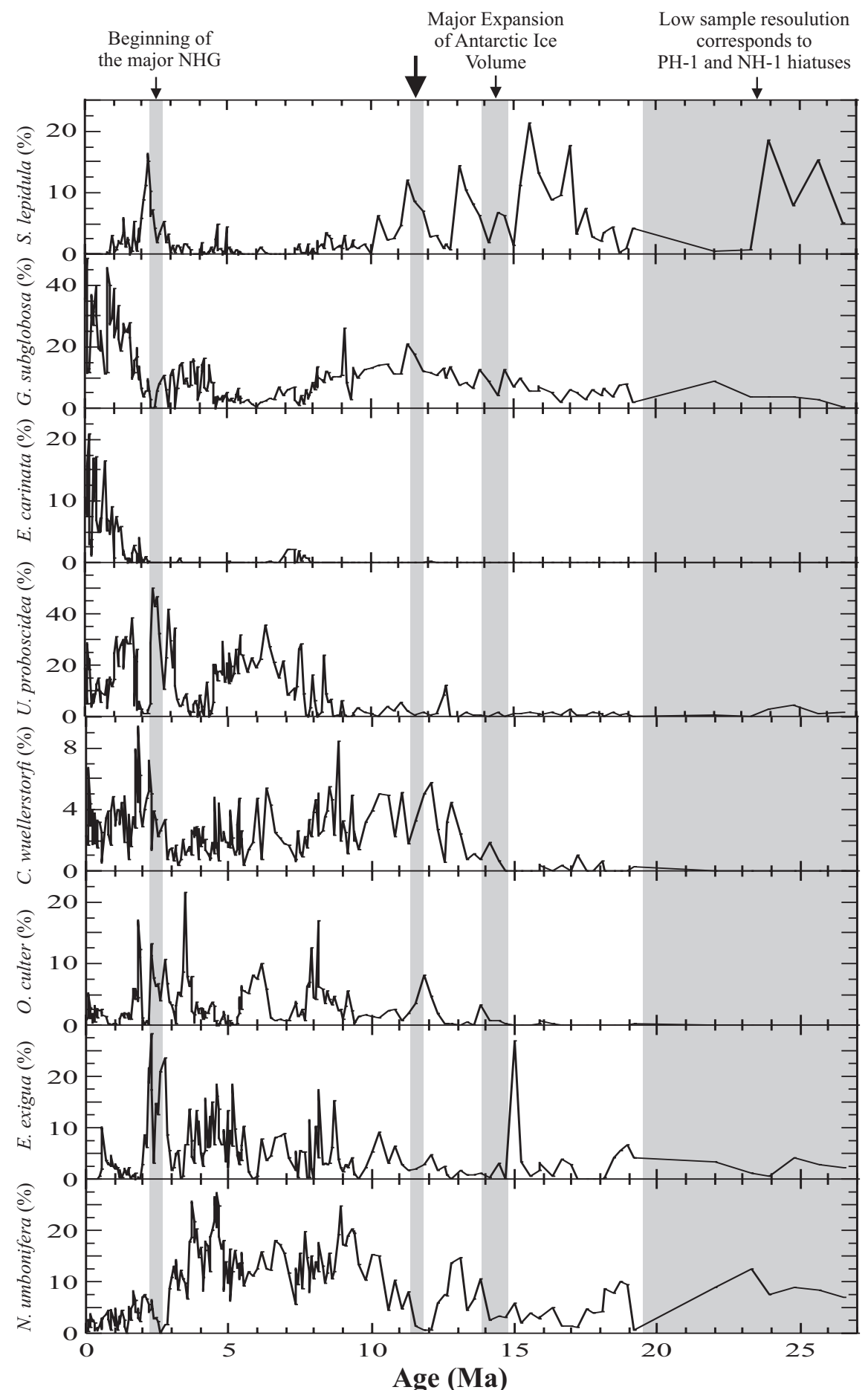

Figure 3. Percent distribution of Nuttallides umbonifera, Epistominella exigua, Osangularia culter, Cibicides wuellerstorfi, Uvigerina proboscidea, Ehrenbergina carinata, Globocassidulina subglobosa and Stilostomella lepidula. An increase in Ehrenbergina carinata and Globocassidulina subglobosa, and major decrease in Nuttallides umbonifera population during 3-2.8 Ma suggest waned influence of Pacific/Indonesian deep waters and increased influence of the North Atlantic Deep Water, coinciding with major increase of the Northern Hemisphere glaciation.

Schmiedl et al. (1997) observed Osangularia culter in high oxygen and low food condition in the south Atlantic. However, there is not much known about this species from the Indian Ocean although it has been found associated with Cibicides wuellerstorfi, a species preferring pulsed food supply and well-oxygenated conditions
(Gupta, 1994). Gupta and Thomas (1999) found assemblages of Cibicides bradyi and Osangularia culter to be indicative of low oxygen environment with warm water and intermediate to continuous food supply in the Indian Ocean, whereas Singh and Gupta (2004) reported this species from well-oxygenated deep water with low organic flux and high seasonality. This species is inferred to indicate better oxygenation and low organic carbon condition.

Stilostomella lepidula is a cosmopolitan taxon, which reflects complicated ecological preferences that are yet to be fully understood. Boersma (1990) suggested that S. lepidula prefers to live in sediments that are organic carbon rich and moderately low in oxygen. Gupta and Thomas (2003) found this species associated with intermediate to high flux of organic food and intermediate seasonality. This species became extinct across the midPleistocene Transition, which has further complicated our understanding of its ecological preference (Gupta, 1993; Kawagata et al., 2006, Bhaumik et al., 2008). Kaiho (1999) suggested that species of Stilostomella group are good indicator of low oxygen and high organic carbon deep-sea conditions. Thomas et al. (1995) also suggested that this group is abundant in organic rich areas. Bhaumik et al. (2008) linked $S$. lepidula disappearance across the midPleistocene Transition to intense cold intervals with deep-sea strong currents.

Uvigerina proboscidea occupies a shallow infaunal microhabitat in organic carbon rich sediments, independent of oxygenation (e.g., Rathburn and Corliss, 1994) and blooms in high productivity regions (e.g., Gupta, 1997; Jannink et al., 1998; Gupta and Thomas, 1999; Gupta et al., 2004), specifically when productivity is high year-round and seasonality of the food supply is low or absent (Loubere, 1998; Ohkushi et al., 2000). This species is most abundant during the late Neogene at several sites in the Indian Ocean and its peak abundances have been inferred to represent times of high surface productivity related to intensified trade winds during strong southwest Indian monsoon that causes widespread upwelling along equatorial divergence in the Indian Ocean (Gupta and Thomas, 1999; Gupta et al., 2001). Murgese and De Deckker (2005) suggested that the distribution of $U$. proboscidea is mainly limited to low latitudes (north of $25{ }^{\circ} \mathrm{S}$ ) at depths 700 to $2000 \mathrm{~m}$ where carbon flux rate is high $\left(=3.5 \mathrm{~g} \mathrm{C} \mathrm{m}^{-2}\right.$ year $\left.^{-1}\right)$ owing to higher primary productivity levels at the sea surface, and low oxygen levels $(<3 \mathrm{ml} / \mathrm{l})$ due to the organic matter oxidation and the presence of oxygen-depleted Indonesian Intermediate Water and North Indian Intermediate Water. The highest abundance of this 
species is between $1700 \mathrm{~m}$ and $2300 \mathrm{~m}$ in the eastern Indian Ocean (Gupta, 1994).

\section{Results and Discussion}

Deep-sea benthic foraminifera show major shifts at Hole 757B, indicating important changes in properties of intermediate to deep waters in the eastern Indian Ocean during the Neogene. Benthic foraminifera underwent first major reorganization during 14.511.5 Ma coinciding with major expansion of the Antarctic ice sheets (Savin et al., 1981) and major increase in deep flow from the Pacific through the Indonesian seaway (Martin and Scher, 2006). In general, high oxygen, low-organic carbon species like Cibicides cicatricosus, Cibicides pseudoungerianus and Oridorsalis umbonatus show higher abundances in the late Oligocene and early Miocene ( 26.5$16 \mathrm{Ma}$ ) punctuated by intermittently higher occurrences of Stilostomella lepidula (Figs. 2 and 3). Cibicides cicatricosus and C. pseudoungerianus disappeared whereas Stilostomella lepidula suffered a major population loss in the early late Miocene during $\sim 12-10 \mathrm{Ma}$, coinciding with a major decrease of $O$. umbonatus population (Fig. 2). Nuttallides umbonifera shows first increase at $\sim 14 \mathrm{Ma}$, and a major stepwise increase during 12-11 Ma ( 11.5 Ma) during which time S. lepidula shows a major decrease (Figs. 2 and 3). Nuttallides umbonifera and S. lepidula, in general, show opposite trends. Cibicides wuellerstorfi shows a major increase $\sim 14 \mathrm{Ma}$ coinciding with major expansion in Antarctic ice volume (Savin et al., 1981), although this species first appeared at Hole 757B in the early Miocene (Fig. 3). Uvigerina proboscidea depicts a major increase at $\sim 8$ Ma coinciding with major intensification of the Indian monsoon (Kroon et al., 1991) (Fig. 3). Benthic fauna underwent a major reorganization following the NHG. For instance, Nuttallides umbonifera shows a stepwise decline beginning at $\sim 3.6$ Ma with lowest values during 3-2.8 Ma, and remained insignificant thereafter. Oridorsalis umbonatus, Globocassidulina subglobosa and Ehrenbergina carinata, on the other hand, show an increase following the NHG (Figs. 2 and 3).

At $\sim 11 \mathrm{Ma}$, Nd isotopic values increase sharply and remained higher until 5.5 Ma at Site 757 (Fig. 2). The high Nd isotopic values during 11-5.5 Ma have been linked to extensive flow of deep ITF water from the Pacific to the Indian Ocean through the Indonesian seaway and its influence in the area of studied site (Martin and Scher, 2006). This suggests that plate motions had carried the studied site into a region with increased influence of deep ITF and waned influence of southern source water like AABW or Antarctic Intermediate Water (AAIW) at $\sim 11 \mathrm{Ma}$ (Martin and Scher, 2006). The benthic faunal data from Hole 757B, including higher N. umbonifera, E. exigua and $O$. culter populations during this time, support observation of Martin and Scher (2006). The cold, corrosive, oligotrophic and better oxygenated deep water from the Pacific Ocean appears to have increased $N$. umbonifera population at $11.5 \mathrm{Ma}$. We do not expect the role of AABW in modulating $N$. umbonifera population at 11.5 Ma for following reasons: (1) Hole 757B was quite shallow well above the influence of AABW, (2) paleolatitude of this hole shows its position close to the present day location, (3) the major expansion of Antarctic glaciation and intense production of AABW occurred much before this increase at $\sim 14$ Ma than the major increase of $N$. umbonifera population at $\sim 11.5 \mathrm{Ma}$, and (4) the Indonesian seaway was wide open and there was unobstructed transport of intermediate to deep ITF from the Pacific to the Indian Ocean. However, whether this intermediate to deep Pacific water mass was of southern origin remains speculative.

During 5.5-3.4 Ma, the low $\mathrm{Nd}$ isotope values do not match with low N. umbonifera percentages at Hole 757B. Rather, N. umbonifera continues to show increased abundance until 3.6 Ma and thereafter it sharply declines (Fig. 2). This mismatch between the two records can be explained by low sample resolution in the study of Martin and Scher (2006) or related to the beginning of constriction of the Indonesian seaway. A sharp decrease in $N$. umbonifera percentages during 3-2.8 Ma suggests substantial reduction or complete shutdown of the Pacific intermediate to deep water flow (deep ITF) to the Indian Ocean through the Indonesian seaway. The reduction of the ITF during 3-2.8 Ma perhaps facilitated increased incursion of NADW in the eastern Indian Ocean, as suggested by increased C. wuellerstorfi, G. subglobosa and E. carinata abundances during this time (Fig. 3).

\section{Conclusions}

The Indonesian Throughflow has played an important role in modulating heat and fresh water budget of the Indian and Pacific Oceans that has driven significant regional and global climate variability during the late Neogene. The benthic foraminiferal data from ODP Hole 757B suggest a major increase in transport of intermediate to deep Indonesian Throughflow (ITF) waters (high Nuttallides umbonifera and Neodynium isotope values) from the Pacific to the Indian Ocean at $\sim 11.5 \mathrm{Ma}$. An abrupt decrease in Nuttallides umbonifera during 3-2.8 Ma suggests a significant reduction/complete shutdown of intermediate to deep Pacific water to the Indian Ocean, coinciding with the final closure of the Indonesian seaway. During this time Cibicides wuellerstorfi, Ehrenbergina carinata and Globocassidulina subglobosa show a major increase at Hole 757B, suggesting increased influence of the North Atlantic Deep Water in the eastern Indian Ocean.

\section{Acknowledgements}

AKG thanks Ocean Drilling Program for providing samples for the present study under Request No. 13626. Council of Scientific and Industrial Research (CSIR), New Delhi is thankfully acknowledged for the financial support (No. 24(0256)/02/EMR-II) and for providing independent Junior Research Fellowship to RKS. Bruce H. Corliss and an anonymous reviewer are thankfully acknowledged for constructive reviews.

\section{References}

Almogi-Labin, A., Schmiedl, G., Hemleben, Ch., Siman-Tov, R., Seg1, M. and Meischner, D., 2000, The influence of the NE winter monsoon on productivity changes in the Gulf of Aden, NW Arabian Sea, during the last $530 \mathrm{ka}$ as recorded by foraminifera. Marine Micropaleontology, v. 40 , pp. 295-319.

Altenbach, A.V. and Sarnthein, M., 1989, Productivity record in benthic foraminifera. in: Berger, W.H. et al. (eds), Productivity of the oceans: present and past. Springer, New York, pp. 255-269.

Altenbach, A.V., Pflaumann, U., Schiebel, R., Thies, A., Timme, S. and Trauth, M., 1999, Scaling percentages and distributional patterns of benthic 
foraminifera with flux rates of organic carbon. Journal of Foraminiferal Research, v. 29, pp. 173-185.

Barbieri, R., 1998, Foraminiferal paleoecology at the Tortonian-Messinian boundary, Atlantic coast of northwestern Morocco. Journal of Foraminiferal Research, v. 28, pp. 102-123.

Barmawidjaja, D.M., Jorissen, F.J., Puskaric, S. and van der Zwaan, G.J., 1992, Microhabitat selection by benthic foraminifera in the northern Adriatic Sea. Journal of Foraminiferal Research, v. 22(4), pp. 297317.

Berggren, W.A., Kent, D.V., Swisher, C.C. and Aubry, M.P., 1995, A revised Cenozoic geochronology and chronostratigraphy. Special Publication of Society of Economic Palaeontologists and Mineralogists, v. 54, pp. 129212.

Bhaumik, A.K., Gupta, A.K., Mohan, K. and Singh R.K., 2008, Disappearance of Stilostomella lepidula (Schwager) across the mid-Pleistocene Transition and its palaeoceanographic implication. Current Science, v. 94(6), pp. 758-764.

Boersma, A., 1990, Late Oligocene to late Pliocene benthic foraminifers from depth traverses in the Central Indian Ocean. in: Duncan, R.A., Backman, J., Peterson, L.C., et al. (eds.), Proceedings of the Ocean Drilling Program, Scientific Results, v. 115, pp. 315-379.

Bremer, M.L. and Lohmann, G.P., 1982, Evidence for primary control of the distribution of certain Atlantic Ocean benthonic foraminifera by degree of carbonate saturation. Deep-Sea Research, v. 29, pp. 987-998.

Burke, S.C., Berger, W.H., Coulbourn, W.T., Vincent, E., 1993, Benthic foraminifera in box core ERDC 112, Ontong Java Plateau. Journal of Foraminiferal Research, v. 23, pp. 19-39.

Cane, M.A. and Molnar, P., 2001, Closing of the Indonesian seaway as a precursor to east African aridification around 3-4 million years ago. Nature, v. 411, pp. 157-162.

Corliss, B.H., 1979, Recent deep-sea benthonic foraminiferal distributions in the southeast Indian Ocean: Inferred bottom water routes and ecological implications. Marine Geology, v. 31, pp. 115-138.

Corliss, B.H., 1983, Distribution of Holocene deep-sea benthonic foraminifera in the southwest Indian Ocean. Deep-Sea Research, v. 30, pp. 95-117.

Corliss, B.H., 1985, Microhabitats of benthic foraminifera within deep-sea sediments. Nature, v. 314, pp. 435-438.

De Stigter, H.C., Jorrisen, F.J. and Van der Zwaan, G.J., 1998, Bathymetric distribution and microhabitat partitioning of live (Rose Bengal stained) benthic foraminifera along a shelf to deep sea transect in the southern Adriatic Sea. Journal of Foraminiferal Research, v. 28, pp. 40-65.

den Dulk, M., Reichart, G.J., van Heyst, S., Zachariasse, W.J. and Van der Zwaan, G.J., 2000, Benthic foraminifera as proxies of organic matter flux and bottom water oxygenation? A case history from the northern Arabian Sea. Palaeogeography Palaeoclimatology Palaeoecology, v. 161 , pp. $337-359$.

Fariduddin, M. and Loubere, P., 1997, The surface ocean productivity response of deeper water benthic foraminifera in the Atlantic Ocean. Marine Micropaleontology, v. 32, pp. 289-310.

Fieux, M., Andrie, C., Charriaud, E., Ilahude, A.G., Metzl, N., Molcard, R. and Swallow, J., 1996, Hydrological and chlorofluoromethane measurements of the Indonesian Throughflow entering the Indian Ocean. Journal of Geophysical Research, v. 101 (C5), pp. 12433-12454.

GEOSECS, 1983, Indian Ocean Expedition, Hydrographic data, 1977-1978. U.S. Govt. Printing Office, Washington, D.C., 5, pp. 1-48.

Gooday, A.J., 1988, A response by benthic foraminifera to the deposition of phytodetritus in the deep sea. Nature, v. 332, pp. 70-73.

Gooday, A.J., 1993, Deep-sea benthic foraminiferal species, which exploit phytodetritus: characteristic features and controls on distribution. Marine Micropaleontology, v. 22, pp. 187-205.

Gooday, A.J., 1994, The biology of deep-sea foraminifers: A review of some advances and their applications in Paleoceanography. Palaios, v. 9, pp. 14-31.

Gooday, A.J., 2003, Benthic foraminifera (Protista) as tools in deep-water paleoceanogrpahy: a review of environmental influences on faunal characteristics. Advances in Marine Biology, v. 46, pp. 1-90.

Gooday, A.J. and Turley, C.M., 1990, Response by benthic organisms to inputs of organic material to the Ocean floor: a review. Philosophical
Transactions of the Royal Society of London, v. A 331, pp. 119-138.

Godfrey, J.S., 1996, The effect of the Indonesian throughflow on ocean circulation and heat exchange with the atmosphere: A review. Journal of Geophysical Research, v. 101 (C5), pp. 12217-12237.

Gordon, A.L. 1986, Interocean exchange of thermocline water. Journal of Geophysical Research, v. 91, pp. 5037-5046.

Gordon, A.L. and Fine, R.A., 1996. Pathways of water between the Pacific and Indian oceans in the Indonesian seas. Nature, v. 379, pp. 146-149.

Gordon, A.L., Giulivi, C.F. and Ilahude, A.G., 2003, Deep topographic barriers within the Indonesian seas. Deep-Sea Research II, v. 50, pp. 2205-2228.

Gupta, A.K., 1990, Species diversity in modern deep-sea benthic foraminifera at Indian Ocean DSDP sites. Indian Journal of Geology, v. 62(3), pp. 166-172.

Gupta, A.K., 1993, Biostratigraphic vs. paleoceanographic importance of Stilostomella lepidula (Schwager) in the Indian Ocean. Micropaleotology, v. 39(1), pp. 47-51.

Gupta, A.K., 1994, Taxonomy and bathymetric distribution of Holocene deepsea benthic foraminifera in the Indian Ocean and Red Sea. Micropaleontology, v. 40(4), pp. 351-367.

Gupta, A. K., 1997, Paleoceanographic and paleoclimatic history of the Somali Basin during the Pliocene-Pleistocene: multivariate analyses of benthic foraminifera from DSDP Site 241 (Leg 25). Journal of Foraminiferal Reseasrch, v. 27, pp. 196-208.

Gupta, A.K., and Satpathy, S.K., 2000, Latest Miocene-Pleistocene abyssal benthic foraminifera from west-central Indian Ocean DSDP Site 236: Paleoceanographic and Paleoclimatic inferences. Journal of the Palaeontological Society of India, v. 45, pp. 33-48.

Gupta, A.K. and Thomas, E., 1999, Latest Miocene-Pleistocene productivity and deep-sea ventilation in the northwestern Indian Ocean (DSDP Site 219). Paleoceanography, v. 14, pp.62-73.

Gupta, A.K. and Thomas, E., 2003, Initiation of Northern Hemisphere glaciation and strengthening of the northeast Indian monsoon: Ocean Drilling Program Site 758, eastern equatorial Indian Ocean. Geology, v.31, pp. 47-50.

Gupta, A.K., Joseph, S. and Thomas E., 2001, Species diversity of Miocene deep-sea benthic foraminifera and water mass stratification in the northeastern Indian Ocean. Micropaleontology, v. 47, pp. 111-124.

Gupta, A. K., Singh, R.K., Joseph, S. and Thomas, E., 2004, Indian Ocean high-productivity event (10-8 Ma): Linked to global cooling or to the initiation of the Indian monsoons? Geology, v. 32, pp. 753-756.

Gupta, A.K., Sarkar, S. and Mukherjee, B., 2006, Paleoceanographic changes during the past $1.9 \mathrm{Myr}$ at DSDP Site 238, Central Indian Ocean Basin: Benthic foraminiferal proxies. Marine Micropaleontology, v. 60, pp. 157166.

Gupta, A.K., Raj, S.M., Mohan, K., De, S., 2008, A major change in monsoondriven productivity in the tropical Indian Ocean during ca 1.2-0.9 Myr: Foraminiferal faunal and stable isotope data. Palaeogeography Palaeoclimatology Palaeoecology, v. 261 (3-4), pp. 234-245.

Herb, R., 1971, Distribution of Recent benthonic foraminifera in the Drake Passage. in: Llano, G.A., Wallen, I.E. (eds.), Biology of the Antarctic Seas IV. Antarctica Research Series, v. 17, pp. 251-300.

Hermelin, J.O.R. and Shimmield, G.B., 1995, Impact of productivity events on benthic foraminiferal faunas in the Arabian Sea over the last 150,000 years. Paleoceanography, v. 10, pp. 85-116.

Jannink, N.T., Zachariasse, W.J. and van der Zwaan, G.J., 1998, Living (rose bengal stained) benthic foraminifera from the Pakistan continental margin (Northern Arabian Sea). Deep-Sea Research, v. 45, pp. 1483-1513.

Kaiho, K., 1999, Effect of organic flux and dissolved oxygen on the benthic foraminiferal oxygen index (BFOI). Marine Micropaleontology, v. 37, pp. 67-76.

Karas, C., Nürnberg, D., Gupta, A.K., Tiedemann, R., Mohan, K. and Bickert, T., 2009, Mid-Pliocene climate change amplified by a switch in Indonesian subsurface throughflow. Nature Geoscience, v. 2, pp. 434-438.

Kawagata, S., Hayward, B.H. and Gupta, A.K., 2006, Benthic foraminiferal extinctions linked to late Pliocene-Pleistocene deep-sea circulation changes in the northern Indian Ocean (ODP Site 722 and 758). Marine Micropaleontology, v. 58, pp. 219-242.

Kroon, D., Steens, T.N.F. and Troelstra, S.R., 1991, Onset of monsoonal related upwelling in the western Arabian sea as revealed by planktonic 
foraminifers. Proceeding Ocean Drilling Program, Scientific Results, v. 117 , pp. 257-263.

Linke, P. and Lutze, G. F., 1993, Microhabitat preferences of benthic foraminifera - a static conceptor a dynamic adaptation to optimize food acquisition? Marine Micropaleontology, v. 20, pp. 215-234.

Lohmann, G.P., 1978, Abyssal benthonic foraminifera as hydrographic indicators in the western South Atlantic Ocean. Journal of Foraminiferal Research, v. 8, pp. 6-34.

Loubere, P., 1996, The surface ocean productivity and bottom water oxygen signals in deep water benthic foraminiferal assemblages. Marine Micropaleontology, 28: 247-261.

Loubere, P., 1998, The impact of seasonality on the benthos as reflected in the assemblages of deep-sea foraminifera. Deep-sea Research I, v. 45, pp. 409-432.

Loubere, P. and Fariduddin, M., 1999, Benthic foraminifera and the flux of organic carbon to the seabed. in: Sen Gupta, K. (Ed.), Modern Foraminifera. Kluwer Academic Publishers, The Netherlands, pp. 181199.

Lutze, G.F., Thiel, H., 1989, Epibenthic foraminifera from elevated microhabitats: Cibicides wuellerstorfi and Planulina ariminensis. Journal of Foraminiferal Research, v. 19, pp.153-158.

Mackensen, A., Schmiedl, G., Harloff, J. and Giese, M., 1995, Deep-sea foraminifera in the South Atlantic Ocean: Ecology and assemblage generation. Micropaleontology, v. 41, pp. 342-358.

Martin, E. E., and Scher, H., 2006, A Nd isotopic study of southern sourced waters and Indonesian Throughflow at intermediate depths in the Cenozoic Indian Ocean, Geochemistry Geophysics Geosystems, v. 7, Q09N02, doi:10.1029/2006GC001302.

Miao, Q. and Thunell, R. C., 1993, Recent deep-sea benthic foraminiferal distributions in the South China and Sulu Seas. Marine Micropaleontology, v. 22, pp.1-32.

Miller, K.G. and Lohmann, G.P., 1982, Environmental distribution of Recent benthic foraminifera on the northeast United States continental slope. Geological Society of America Bulletin, v. 93, pp.200-206.

Murgese, D.S. and De Deckker, P., 2005, The distribution of deep-sea benthic foraminifera in core tops from the eastern Indian Ocean. Marine Micropaleontology, v. 56, pp. 25-49.

Nishimura, S. and Suparka, S. 1997, Tectonic approach to the Neogene evolution of Pacific-Indian Ocean seaways. Tectonophysics, v. 281, pp. 1-16.

Nomura, R., 1991, Oligocene to Pleistocene benthic foraminifer assemblages at Site 754 and 756, Eastern Indian Ocean. Proceedings of the Ocean Drilling Program, Scientific Results, v. 121, pp. 31-75

Ohkushi, K., Thomas, E. and Kawahata, H., 2000, Abyssal benthic foraminifera from the Northwestern Pacific (Shatsky Rise) during the last 298 kyr. Marine Micropaleontology, v. 38, pp. 119-147.

Peirce, J., Weissel, J., et al., 1989, Proceedings of the Ocean Drilling Program, Initial Reports, v. 121, pp. 359-453.

Rathburn, A.E. and Corliss, B.H., 1994, The ecology of living (stained) benthic foraminifera from the Sulu Sea. Paleoceanography, v. 9, pp. 87-150.

Savin, S.M., Douglas, R.G., Keller, G., Killingley, J.S., Shaughnessy, L., Sommer, M.A., Vincent, E. and Woodruff, F., 1981, Miocene benthic foraminiferal isotope records: A synthesis. Marine Micropaleontology, v. 6 , pp. $423-450$.

Schmiedl, G., Mackensen, A., 1997, Late Quaternary paleoproductivity and deep water circulation in the eastern South Atlantic Ocean: evidence from benthic foraminifera. Palaeogeography, Palaeoclimatology, Palaeoecology, v. 130, pp. 43-80.

Schmiedl, G., Mackensen, A. and Muller, P.J., 1997, Recent benthic foraminifera from the eastern South Atlantic Ocean: Dependence on food supply and water masses. Marine Micropaleontology, v. 32, pp. 249287.

Schnitker, D., 1974, West Atlantic abyssal circulation during the past 120,000 years. Nature, v. 248, pp. 385-387.

Schnitker, D., 1980, Quaternary deep-sea benthic foraminifers and bottom water masses. Annual Review of Earth and Planetary Sciences, v. 8, pp. 343-370.

Sen Gupta, B.K. and Machain-Castillo, M.L., 1993, Benthic foraminifera in oxygen-poor habitats. Marine Micropaleontology, v. 20, pp.183-201.

Singh, R.K. and Gupta, A.K., 2004, Late Oligocene-Miocene paleoceanographic evolution of the southeastern Indian Ocean: Evidence from deep-sea benthic foraminifera (ODP Site 757). Marine Micropaleontology, v. 51, pp. 153-170.

Smart, C.W. and Murray, J.W., 1994, An early Miocene Atlantic-wide foraminiferal paleoceanographic event. Palaeogeography Palaeoclimatology Palaeoecology, v. 108, pp. 139-148.

Streeter, S., 1973, Bottom water and benthonic foraminifera in the North Atlantic-glacial-interglacial contrasts. Quaternary Research, v. 3, pp. 131141

Streeter, S. and Shackleton, N.J., 1979, Paleocirculation of the deep North Atlantic: 150,000 year record of benthic foraminifera and oxygen-18. Science, v. 203, pp. 168-171.

Thomas, E., 1992, Cenozoic deep-sea circulation: evidence from deep-sea benthic foraminifera. AGU Antarctic Research Series, v. 56, pp. 141165 .

Thomas, E., Booth, L., Maslin, M. and Shackleton, N.J., 1995, Northeastern Atlantic benthic foraminifera during the last 45,000 years: productivity changes as seen from the bottom up. Paleoceanography, v. 10, pp. 545562.

Tomczak, M. and Godfrey, J.S., 2003, Regional Oceanography: An Introduction, $2^{\text {nd }}$ edition. Daya, New Delhi, 390p.

Uchio, T., 1960, Biological results of the Japanese Antarctic expedition, benthonic foraminifera of the Antarctic Ocean. Seto Marine Biology Laboratory, Special Publication, v. 12, pp. 1-21.

Van Anken, H.M., Punjanan, J., Saimima, S., 1988, Physical aspects of the flushing of the East Indonesian basins. Netherlands Journal of Sea Research, v. 22, pp. 315-339.

Van Leeuwen, R.J., 1989, Sea floor distribution and late Quaternary faunal patterns of planktonic and benthic foraminifera in the Angola Basin. Utrecht Micropaleontology Bulletin, v. 38, pp. 1-287.

Warren, B.A. and Johnson, G.C., 2002, The overflows across the Ninetyeast Ridge. Deep-Sea Research II, v. 49, pp. 1423-1439.

Wyrtki, K., 1987, Indonesian through flow and the associated pressure gradient. Journal of Geophysical Research, v. 92, pp. 12941-12946.

\section{Annexure 1}

List of species used in the present study with their full references

Cibicides cicatricosus = Anomalina cicatricosa Schwager, 1866, "Novara" Exped., Geol. Theil., 2: p.260, pl.7, fig. 108

Cibicides pseudoungerianus $=$ Trucatulina pseudoungerianus Cushman, 1922, p. 97, pl.20, fig. 9.

Cibicides wuellerstorfi $=$ Anomalina wuellerstorfi Schwager, 1866, "Novara" Exped., Geol. Theil., 2(1): p.258, pl.7, fig. 105

Ehrenbergina carinata $=$ Ehrenbergina carinata Eade, 1964, New Zealand Jour. Marine and Freshwater Res., 1(4): p. 448, Figs. 8(9), 9(1-4)

Epistominella exigua $=$ Pulvinulina exigua Brady, 1884, Rept. Voy. H.M.S. challenger, Zool., no.9, p. 696, pl.103, figs. 13,14

Globocassidulina subglobosa $=$ Cassidulina subglobosa Brady, 1884, Rept. Voy. H.M.S. challenger, Zool., no.9, p. 430, pl.54, figs. 17a-c

Nuttallides umbonifera $=$ Pulvinulinella umbonifera Cushman, 1933, Contr. Cushman Lab. Foram. Res., 9(4), p. 90, p1.9, fig. A-C

Oridorsalis umbonatus $=$ Rotalina umbonata Reuss, 1851, Zeitschr. Deutsh. Geol. Ges., 3: p. 72, pl.5, fig. 32,

Osangularia culter $=$ Planorbulina culter Parker and Jones, 1865, Roy. Soc. London, Philos. Trans., 155: p. 421, pl. 19, fig. 1

Stilostomella lepidula $=$ Nodosaria lepidula Schwager, 1866, "Novara" Exped., Geol. Theil., 2: p.210, pl.5, fig. 27, 28

Uvigerina proboscidea $=$ Euvigerina proboscidea Schwager, 1866, "Novara" Exped., Geol. Theil., 2: p.250, pl.7, fig. 96 


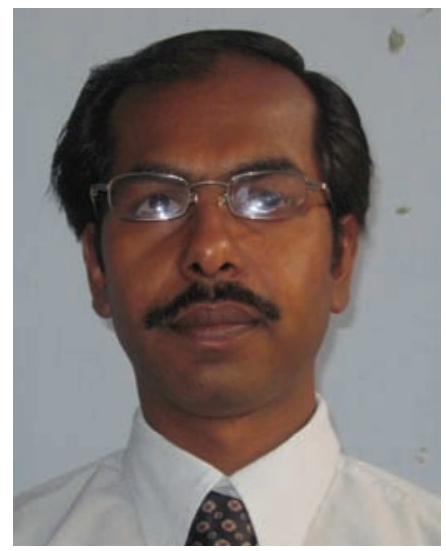

Raj Kumar Singh received M.Sc. degree in Geology from Banaras Hindu University, Varanasi, India in the year 2001 and later joined Department of Geology and Geophysics, Indian Institute of Technology as a CSIR, Junior Research Fellow under kind guidance of Prof. Anil K. Gupta and awarded Ph.D. in 2009. His research interest includes Micropaleontology, Paleoceanography, Paleoclimatology and Hydrogeology. He is presently working as Hydrogeologist in Central Ground Water Board, Mid-Eastern Region, Patna.

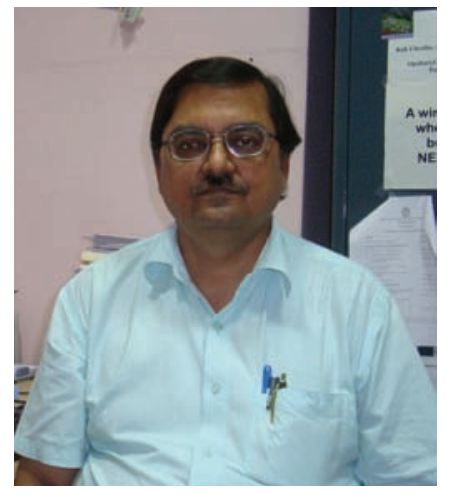

Anil K. Gupta, Professor at the Indian Institute of Technology, Kharagpur, has extensively worked on Neogene foraminifera from Ocean Drilling Program (ODP) cores to understand paleoceanographic and paleoclimatic changes in the Indian Ocean with special reference to the Indian monsoon. Dr. Gupta has innovatively used deep-sea benthic foraminifera as well as planktic foraminifera to understand Indian monsoon variability and its impact on surface and deep ocean. 